\title{
施設紹介
}

\section{Baylor College of Medicine, Department of Surgery}

\author{
東京電機大学理工学部応用電子工学科 佐久間一郎
}

筆者は1990年 8 月より1991年 9 月まで，米国 テキサス州ヒューストンにあるテキサスメディ カルセンター内の Baylor College of Medicine (ベイラー医科大学) Department of Surgery にて東京電機大学丹羽記念会海外研修生として 人工藏器に関する研究に従事した。本稿ではべ イラー医科大学について若干の紹介を行う。

ベイラー医科大学は1900年に University of Dallas の医学部として設立され, 3 年後, Waco にある Baylor University の学部となり, 1943 年にダラスからヒューストンに移転した。1947 年にヒューストンに移転し, テキサスメディカ ルセンター内の最初の教育機関となった。1969 年に Baylor University から分離し, 独立した 教育研究機関となり, Baylor College of Medicine という名称を持つようになった。べイ ラ一医科大学はアメリカ南西部唯一の私立の医 科大学である。

関連病院としては, Texas Children’s Hospital,Methodist Hospital, Ben Taub General Hospital, Jefferson Davis Hospital, Quentin R. Mease Community Hospital, Vaterans Administration Medical Center, Institute for Rehabilitation and Research,St. Luke's Episcopal Hospital があり，そこでベイラー医 科大学に所属する医師達は診療を行っている。

研究機関としては, Influenza Research Center, The Children's Nutrition Center, DeBakey Heart Center, Glaucoma Service and Research Laboratory, Baylor's Cystic Fibrosis Center, Sleep Disorders Center, Baylor's Pain Control and Bio-feedback
Clinic, Center for Bio-technology がある。 本学があるテキサスメディカルセンターには Texas Heart Institute, University of Texas System Cencer Canter M.D. Anderson Hospital and Tumor Institute at Houston な ぞ多くの研究機関が存在し，その間の共同研究， 情報交換も盛んであり，世界有数の医療セン夕 一となっている。

本学の Chancellor であり, 筆者が滞在した Department of Surgery の Chairmanでもある Dr. DeBakeyは世界的な心臟外科医として有 名であり，彼のグループは1964年に自らが開発 した人工心肺装置を使用して，最初の心臟のバ イパス手術を成功させている。博士はまた， 50 種以上の医療機器の開発も手がけており, 外科 の研究室には, 日本の大学の工学部の機械工作 室に勝るとも劣らない設備, 人員を有する機械 工作工場，ならびに，エレクトロニクス部門を 有しており, 病院内の各種医療機器の開発, な らびにそのメンテナンスにあたっている。

筆者は Department of Surgeryの能勢之彦 教授の研究室に 1 年 2 ヶ月滞在した。教授はク リーブランドクリニックの人工藏器研究所の前 所長であり, 各種人工藏器の研究を長年にわた り行ってこられた研究者である。

助教授は工学系研究者である高谷節雄博士で あり, 医学側研究者と工学側研究者のコンビネ ーションにて研究が行われている。

研究室の体制は能勢教授, 高谷助教授のもと で, Faculty 5 名, 研究員 1 名, 秘書 1 名から構 成されている。このほかに機械工作室に 6 名, 電気機器工作室に 3 名, 動物実験室に 4 名のス 
タッフがいる。また, 週一回臨床系の外科の教 授である Professor Noon の研究スタッフとミ ーティングを持ち, 臨床現場との連携をはかっ ている。

研究課題は主として循環系人工臓器の開発で あり, 以下のテーマについて研究が行われてい る。

\section{A. Electro-Mechanical LVAD の開発}

補助心臓装置 (VAD-Ventricle Assist Device）としては, 従来, 空気駆動型補助心藏 が使用されている。空気駆動型補助心臓は構造 が簡単であるが, 駆動部である空気ポンプを体 外に置き，空気をポンプに送るためのチューブ 経皮的につながねばならず，感染の危険が常に 存在する。この問題点を解決すべく, 駆動部に DC ブラシレスモータを使用し，アクチュエー 夕をも体内に埋込む方式の永久使用を目的と した補助人工心臓システムの開発を行っている。 駆動部の小型化にて夫をこらした，またポンプ 内面をゼラチンでコーティングする Biolization 技術を用いてポンプの抗血栓性を向上さ せている。

\section{B. Electromechanical Total Artificial Heart の開発}

補助心臓とは異なり, 生体の心臓を完全に置 換する体内埋め込み型の完全置換型人工心臓の 開発を行っている。上記ポンプ 2 ピースを 1 個 の駆動系で駆動する方式をとり，小型化をはか つている。すなわち左右のポンプを1個のアク チュエータで交互に駆動する方式を使用してい る。また，ポンプを埋め込んだ際に体腔内のス ペースにうまくフィットするようにするために, ポンプの形状, 特にインフローボート, アウト フローボートの位置, 方向を最適化することを 目的に, Methodist Hospitalにて行われる心臓 移植手術の際に, 開発中の人工心臓モデルを患 者胸腔内に埋め込み，その構造を検討する Fitting Studyによりその外形寸法, 形状は決定さ
れている。

\section{C. 人工心肺用無泊動流ポンプの開発}

開心術時の人工心肺用ポンプ，あるいは経皮 的循環補助装置用ポンプなどとして48時間連続 使用可能な小型遠心ポンプを日本の医療機器メ 一カである日機装と共同で開発している。従来 使用されているBio Pumpなどに比較して格 段に小形, 軽量化されており, 緊急用の用途に も使用可能である。

\section{D. 補助循環用無拍動流ポンプの開発}

現在市販または開発中の遠心ポンプはその多 くが人工心肺用ポンプとして設計されているた め, その連続使用可能時間は, 2 日程度が限度 である。遠心ポンプを開心術後心原性ショック 時の補助循環に応用したり, ECMO (Extra Corporeal Membrane Oxygenation) に応用 する場合には，一層長期間使用可能なポンプが 必要となる。このように連続使用時間が限られ ている原因はポンプ内部の羽根車のシャフトを 支持するベアリングとポンプ室の間のシールの 劣化による血液の漏出, あるいは軸・シール部 での血栓形成であり, 駆動軸やシールが存在す る限り解決が困難な問題である。DC プラシレ スモー夕を遠心ポンプ羽根車に組み込み，また 特殊な支持方式を採用することにより，シール レス化と小型化の雨者を実現し，長時間耐久性 のあるポンプの開発をめざしている。

またこれとは別に，NASA（アメリカ航空字 宙局）と共同で，モータをロー夕に組み込んだ 小形軸流血液ポンプの開発を行っている。

\section{E. 新しい人工免疫システムに関する研究}

血液を人工物と接触させることにより，生体 の免疫系を賦活させ，なんらかの疾患の治療を 行うための基礎的研究として, 従来あまり検討 されていない銅アモルファスの微細ファイバに よる白血球, リンパ球の吸着現象と, その温度 依存性について基礎的な検討を行っている。 